Original Research

\title{
Determination of Yield and Yield Components of Some Oat Cultivars, Grown in the Eastern Anatolia Conditions, by Correlation, Path and Cluster Analysis
}

\author{
Fevzi Altuner* \\ Van Yuzuncu Yil University, Gevas Vocational School, Department of Plant and Animal Production, Van-Turkey
}

Received: 9 April 2021

Accepted: 27 July 2021

\begin{abstract}
This study was carried out to determine the effects of some agronomic characteristics on grain yield (GY) in 12 oat cultivars by correlation, path and cluster analysis. The GY varied between 2563-4134 kg/ha and the highest GY was obtained from Haskara, Seydisehir and Dirilis cultivars and the lowest GY was taken from Chekota cultivar. According to the correlation results, positive significant relationships were found between plant height $(\mathrm{PH})$ with harvest index $(\mathrm{H}) \mathrm{I}$ and negative significant correlaltion with panicle length (PL), number of grains per panicle (NGP), thousand-grain weight (TGW), and total yield (TY). Significant negative relationships among the number of panicles per square meter (NPSM) with NGP and grain weight per panicle (GWP) have been identified. There was a significant positive correlation between the PL and NGP. Positive significant relationships between the NGP with GWP and negative significant relationships with HI have emerged. There is a negative and significant relationship between HI and TY. According to the results of the path analysis, it was determined that the highest positive direct effect on GY was provided by the NPSM $(\mathrm{P}=0.699,25.32 \%)$, while the highest negative direct effect was TY $(\mathrm{P}=-2.190,36.42 \%)$. According to the cluster analysis results of the characteristics examined, it was understood that the cultivars of oat were $64.96 \%$ similar and $35.04 \%$ different.
\end{abstract}

Keywords: (Avena sativa L.), correlation, path, clustering, cereals

\section{Introduction}

Cool climate cereals occupy significant place in cultivated crops, and oats rank third in the world in terms of cultivation area [1]. In this respect, oats have 9.4 million ha of cultivation, 23.1 million tons of production, and $2453.1 \mathrm{~kg} / \mathrm{ha}$ yield in the world [2]. With a wide range of habitats and rich vegetation in Turkey [3], oats ranks fourth behind wheat, barley and rye with 113.3 thousand ha cultivation area, 314.5 thousand tons production and $2780 \mathrm{~kg} / \mathrm{ha}$ yield [4]. Marmara and Central Anatolia Region have $85 \%$ of Turkey's oat production. 
Oat, which has a biological protein value like other cereals, is among the cereal grains with its crude oil value reaching $11 \%$. Although oat is mostly used as animal feed, its use is becoming widespread in pharmacies, cosmetics and human nutrition day by day [5]. Oats are included in many food products due to their low production cost, high level of dietary fiber, and $\beta$-glucan content, and their importance in nutrition is increasing [6]. In this respect, it is necessary to increase the cultivation area and production of oats to meet the increasing demand. Although it adapts better to bad land conditions, it is generally vulnerable to cold and drought, and in regions where the continental climate is dominant, oats cultivation for autumn is limited and it is tried to be grown by alternative cultivation methods such as embedding sowing [7]. In this respect, it is necessary to develop new cultivars that are tolerant of short vegetation periods and extreme climatic conditions to be able to grow oats in places where other cool climate grains are grown [8].

Yield is a complex character that depends on many genes that are highly affected by environmental conditions, so for a successful breeding program, studying the traits that affect it, rather than yield, provides more effective results. The relationship between yield and yield properties is often explained by correlation analysis, but more detailed results are obtained with path analysis for the same purpose. Inbreeding studies set up conducted to obtain new cultivars with high yield and quality, the relationship between agronomic traits and grain yields is examined, and path analysis reveals the direct and indirect effect rates of characters on yield [9-10]. Similarly, the cluster analysis, which is used to increase the success of breeding programs, determines the similarity between genotypes and prevents the reuse of similar individuals. In many studies conducted for this purpose, their genetic diversity was determined by grouping the agronomic characteristics of oat genotypes through cluster analysis [5].

In this study, the agronomic characteristics of 12 oat cultivars grown with the embedding sowing method were examined by correlation, path, and cluster analysis to be used in breeding programs, and thus, it was tried to determine the selection criteria that can be addressed in breeding studies.

\section{Materials and Methods}

\section{Climatic Values of the Research Seasons}

Van is a city located in eastern Anatolia in Turkey, has the typical features of continental climate. The climate data of the 2017-2018 and 2019-2020 growing seasons where the research was conducted in the Campus of Van Yuzuncu Yil University around of Technokent is shown in Table 1 [11].

The total rainfall in the $2017-2018$ season is $306.1 \mathrm{~mm}$, $230.3 \mathrm{~mm}$ in the 2019-2020 season, and the average rainfall for long years (AoLY) total is $374.2 \mathrm{~mm}$ in the area with the classic features of the continental climate. In both seasons of the experiment conducted in dry conditions, it is observed that a lower rainfall than AoLY was recorded, but especially in the 20192020 season, $76.3 \mathrm{~mm}$ less rainfall than the previous

Table 1. Some climatic values of the research seasons and long years averages (Anonymous, 2018-2020).

\begin{tabular}{|c|c|c|c|c|c|c|c|c|c|}
\hline \multirow{2}{*}{ Months } & \multicolumn{3}{|c|}{ Rainfall (mm) } & \multicolumn{3}{|c|}{ Temperature $\left({ }^{\circ} \mathrm{C}\right)$} & \multicolumn{3}{|c|}{ Relative humidity (\%) } \\
\hline & $2017-2018$ & $2019-2020$ & AoLY* & $2017-2018$ & $2019-2020$ & AoLY* & $2017-2018$ & 2019-2020 & AoLY* \\
\hline September & - & 0.8 & 20.4 & 20.3 & 18.8 & 17.8 & 29 & 42.7 & 43.9 \\
\hline October & 27.4 & 24.1 & 38.2 & 11.5 & 13.4 & 11.2 & 44.2 & 32.9 & 57.3 \\
\hline November & 49.3 & 22.9 & 48.8 & 5.9 & 5.2 & 4.8 & 62.1 & 48.2 & 64.2 \\
\hline December & 16.9 & 46.7 & 45.1 & 2.8 & 3 & 0.2 & 63.5 & 51.3 & 67.5 \\
\hline January & 27.4 & 31.1 & 45.6 & 0.7 & -1.7 & -3.1 & 64 & 59.5 & 66.7 \\
\hline February & 21.2 & 21.3 & 43.4 & 2.7 & -1.5 & -2.5 & 64.4 & 63.8 & 67.2 \\
\hline March & 32.6 & 24.4 & 36.4 & 8.2 & 2.7 & 1.5 & 51.5 & 63.4 & 65.4 \\
\hline April & 33.4 & 36.2 & 35.6 & 10.2 & 7 & 7.6 & 51.7 & 56.1 & 59.3 \\
\hline May & 73.5 & 15.3 & 35.9 & 14.3 & 15.2 & 13.1 & 58.7 & 51.9 & 55.1 \\
\hline June & 24.4 & 7.2 & 18.6 & 19.5 & 21 & 18.5 & 45.6 & 45.4 & 47.1 \\
\hline July & - & 0.4 & 6.2 & 24.8 & 23.2 & 22.2 & 29.6 & 39 & 42.3 \\
\hline Total & 306.1 & 230.3 & 374.2 & - & - & - & - & - & \\
\hline Average & & & & 10.98 & 9.7 & 8 & 51.3 & 50.3 & 52.6 \\
\hline
\end{tabular}

* AoLY: average rainfall of long years 
Table 2. Some physical and chemical properties of the trial area soils.

\begin{tabular}{|c|c|c|c|c|c|}
\hline Depth $(\mathrm{cm})$ & Texture & $\mathrm{pH}$ & Total salt $(\mu \mathrm{S} / \mathrm{cm})$ & Lime $(\%)$ & Organic matter $(\%)$ \\
\hline $0-20$ & Sandy Loam & 7.65 & 188.0 & 8.80 & 0.94 \\
\hline $20-40$ & Sandy Loam & 7.73 & 152.1 & 9.10 & 0.63 \\
\hline
\end{tabular}

season and $143.9 \mathrm{~mm}$ less than the AoLY was observed, especially in plants, May, which is a period of stalk, is quite arid in this season. The average temperature data of the growing seasons were $10.9^{\circ} \mathrm{C}$ in the $2017-2018$ season, $9.7^{\circ} \mathrm{C}$ in the $2019-2020$ season, and $8^{\circ} \mathrm{C}$ in the AoLY similar to each other, but the temperatures in March and April in the 2019-2020 season were quite low and immediately doubled in May $\left(15.2^{\circ} \mathrm{C}\right)$ is understood. It is seen that the relative humidity average values in the region range between $50.3-52.6 \%$ (Table 1).

\section{Properties of the Trial Soils}

The analysis results of the soil samples taken from $0-20 \mathrm{~cm}$ and $20-40 \mathrm{~cm}$ depth at different points in the experimental area showed that the texture was sandyloam, the $\mathrm{pH}$ was close to neutral, the total salt value was low, the amount of lime was medium and organic matter was insufficient (Table 2).

\section{Plannining, Establishing and Conducting the Research}

In the research, 12 oat cultivars (Kahraman, Kirklar, Fetih, Haskara, Sari, Dirilis, Yeniceri, Faikbey, Seydisehir, Albatros, Arslanbey and Chekota) were used. Information of the cultivars registered was shown on Table 3.
The trials established on the based on the Randomized BlocksTrial design were carried out on 36 plots with 3 replications and the length of the plots was $6 \mathrm{~m}$ and the row spacing was $20 \mathrm{~cm}$.

Planting was carried out in both seasons by embedding sowing method in the first week of December with a test drill. Embedding sowing method was applied to protect the plants from winter damage through snow cover, to take out in early spring, which cannot be entered into the field due to heavy temper, and to benefit from the precipitation of this period.

Embedding sowing is a method that can be done in the forms of sowing to the rows or broadcasting and is practically the same as these. Sowing is done in the late period just before snowfall. Thus, plant emergence is not within 10-15 days after sowing, but in early spring (March) just after the snow cover is removed. Therefore, no specific picture of Embedding Sowing Method has been found in the records.

In the experiments, diammonium phosphate DAP (18-46-0) fertilizer was given in the amount of $3 \mathrm{~kg} / \mathrm{da}$ $\mathrm{N}$ and $7.6 \mathrm{~kg} / \mathrm{da} \mathrm{P}_{2} \mathrm{O}_{5}$ with sowing. Mechanical weed control was made when needed in the experiments conducted in dry conditions.

Measurements and harvesting were carried out in $4 \mathrm{~m}^{2}(0.8 \times 5 \mathrm{~m})$ by removing one row from the sides and $50 \mathrm{~cm}$ from the heads as an edge effect. After the harvest with a sickle in July, the stalked product taken from the parcels was blended with the spike

Table 3. Registration information of oat cultivars used in the research.

\begin{tabular}{|c|c|c|c|}
\hline Range & Cultivar & Supplying Organization & Register Date \\
\hline 1 & Kahraman & Thrace Agricultural Research Institute & 11.4 .2014 \\
\hline 2 & Kirklar & Trakya Tarımsal Araştırma Enstitüsü & 11.4 .2014 \\
\hline 3 & Fetih & Aegean Agricultural Research Institute & 11.4 .2104 \\
\hline 4 & Haskara & Aegean Agricultural Research Institute & 26.3 .2015 \\
\hline 5 & Sari & Aegean Agricultural Research Institute & 11.4 .2014 \\
\hline 6 & Dirilis & Bahri Dagdas International Agricultural Research Institute & 13.4 .2017 \\
\hline 7 & Yeniceri & Bahri Dagdas International Agricultural Research Institute & 12.4 .2013 \\
\hline 8 & Faikbey & Bahri Dagdas International Agricultural Research Institute & 14.4 .2004 \\
\hline 9 & Seydisehir & Bahri Dagdas International Agricultural Research Institute & 14.4 .2004 \\
\hline 10 & Albatros & Ata Tohumculuk İşl. San. ve Ticaret A.Ş. & 26.3 .2015 \\
\hline 11 & Arslanbey & Kahramanmaras Sutcu Imam Unv. Faculty of Agriculture & 13.4 .2017 \\
\hline 12 & Chekota & Gecitkusagi Agricultural Research Institute & 30.4 .1986 \\
\hline
\end{tabular}


threshing machine. Total yield and grain yield measurements were made from a harvest area of $4 \mathrm{~m}^{2}$ for each parcel, and other measurements and observations were made from 20 plants randomly selected in the parcels [7].

\section{Statistical Analysis of the Research}

For the statistical analysis of the study, IBM, SPSS 23.0, OPSTAT, and MINITAB V.16.0 programs were used for the cluster analysis of the examined features, and multiple comparisons were performed with LSD 0.05 test.

\section{Results and Discussion}

The differences between all the examined characteristics of oat cultivars according to the combined years were found to be significant (Table 4).

Plant heights of the cultivars varied between 69.0-97.6 cm, the highest value was determined in Faikbey and lowest in Albatros (Table 4). Since the total rainfall $(230.3 \mathrm{~mm})$ received in the 2019-2020 season was lower than the previous season and the May precipitation, which was effective in shaping the grading with stall, was very low, the average plant height decreased compared to the combined years. Therefore, the plant height affected by environmental factors and care practices [12], was formed shorter than Dumlupinar et al. [8]. It was found that there is a negative relationship between plant height and yield and tall genotypes have $30 \%$ fewer grain yields than short ones [8].

The number of panicles per square meter in cultivars varied between 275.1-382.6, while Arslanbey and Kahraman cultivars were in the highest group, Chekota was found at the lowest level (Table 4). The number of clusters per square meter obtained in the study is higher than Naser and Al-mothefer [13].

The panicle lengths of the cultivars varied between 13.0-17.9 cm, while Haskara and Janissary cultivars were in the highest group, Fetih was in the lowest group (Table 4). The panicle lengths obtained in the study were similar to Erbas and Mut [14] and lower than Kilinc [15]. The low rainfall in the 2019-2020 season (especially in May) and the low temperature in March-April are the effects of the decrease in the panicle lengths. In seasons where extreme temperature and precipitation values are observed, yield and quality decrease [10], causing a negative effect at the beginning of the cluster and during the panicle formation period [16].

The number of grains per panicle of cultivars was between 38.1-83.4, the Haskara variety was the highest and the Fetih variety was the lowest (Table 4). In the study, the number of grains per panicle showed a wide variation, and low results were obtained from similar studies [15]. This is due to the variability in climate data between years. Because genotype and environment interaction significantly affect the number of grains per cluster [8].

Table 4. Yield and yield components of oat cultivars according to combined years.

\begin{tabular}{|c|c|c|c|c|c|c|c|c|c|c|c|c|c|c|c|c|c|c|}
\hline Cultivars & $\begin{array}{l}\mathrm{PH} \\
(\mathrm{cm}\end{array}$ & & $\begin{array}{l}\text { NPSN } \\
\text { (numb }\end{array}$ & & PL & & $\begin{array}{r}\text { NGP } \\
\text { (numb }\end{array}$ & & $\begin{array}{r}\text { GW } \\
(\mathrm{g})\end{array}$ & & $\begin{array}{r}\text { TG } \\
(\mathrm{g})\end{array}$ & & $\begin{array}{r}\mathrm{GY} \\
(\mathrm{kg} / \mathrm{h}\end{array}$ & & TY $(\mathrm{k}$ & & $(\%)$ & \\
\hline Albatros & 69.0 & $\mathrm{~g}$ & 305.8 & de & 14.7 & ef & 46.8 & c-e & 2.10 & $\mathrm{~b}$ & 22 & $\mathrm{fg}$ & 462 & $\mathrm{~cd}$ & 9944 & $\mathrm{c}$ & 0.36 & $\mathrm{~cd}$ \\
\hline Arslanbey & 6.7 & ef & 382. & $\mathrm{a}$ & 15.3 & 1 & 0 & & 1.68 & $\mathrm{~cd}$ & 50.5 & b & 3412 & & & & 8 & $\mathrm{a}-\mathrm{c}$ \\
\hline Chekota & 86.8 & $\mathrm{bc}$ & 275.1 & $\mathrm{f}$ & 15.6 & s & 53.8 & 1 & 1.75 & $\mathrm{~cd}$ & 37.1 & $\mathrm{bc}$ & 2563 & c & & 1 & 0.33 & de \\
\hline Dirilis & 9.2 & g & 322.4 & $\mathrm{~cd}$ & 16.5 & $d$ & 51.6 & 1 & 1.38 & . & 30.9 & g & 4015 & $\mathrm{ab}$ & & & 0.39 & $\mathrm{ab}$ \\
\hline Faikb & 7.6 & $\mathrm{a}$ & 3072 & $\mathrm{de}$ & 16.8 & $a_{-}$ & 494 & $\mathrm{~b}$ & 1.68 & $\mathrm{~cd}$ & 418 & $\mathrm{a}$ & 2950 & & & 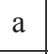 & 0.34 & de \\
\hline Fetih & 61.8 & $\mathrm{~h}$ & 3211 & $c d$ & 130 & $\mathrm{~g}$ & 381 & $\mathrm{~g}$ & 1.38 & 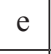 & 336 & of & 2965 & 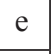 & 72 & $d$ & 0.41 & $\mathrm{a}$ \\
\hline Haska & 3.2 & $a b$ & 282.3 & c & 17.9 & $\mathrm{a}$ & 834 & $\mathrm{a}$ & 2.33 & 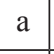 & 36.2 & b d & 4134 & 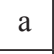 & 14 & 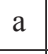 & 0.31 & e \\
\hline Kahrar & 1.6 & $\mathrm{fg}$ & 3 & a & 13 & $\mathrm{fg}$ & 8 & $I_{\xi}$ & 1.41 & 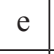 & 35.2 & 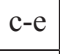 & 668 & ( & & $\mathrm{a}$ & 0.31 & e \\
\hline Kirklar & 72.8 & $e-g$ & 366.7 & av & 13.6 & $\mathrm{fg}$ & 45.5 & $d-f$ & 1.64 & u & 34.7 & wi & 3468 & $\mathrm{~cd}$ & 10136 & 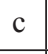 & 0.36 & $\mathrm{~d}$ \\
\hline Sari & 83.8 & $\mathrm{~cd}$ & 309.9 & d & 14.3 & & 45.5 & $\mathrm{~d}-\mathrm{f}$ & 1.90 & $0 \mathrm{C}$ & 42.3 & 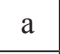 & 3772 & 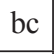 & & 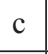 & 0.36 & $b-d$ \\
\hline Seydisehir & 88.3 & $\mathrm{bc}$ & 361.0 & $\mathrm{ab}$ & 16.5 & $b-d$ & 50.5 & b-d & 1.75 & $\mathrm{~cd}$ & 36.1 & - & 4078 & $\mathrm{ab}$ & & $\mathrm{ab}$ & 0.32 & $\mathrm{e}$ \\
\hline Yeniceri & 79.2 & de & 343.5 & $\mathrm{bc}$ & 17.9 & $\mathrm{ab}$ & 52.2 & bc & 1.71 & $\mathrm{~cd}$ & 37.3 & $\mathrm{bc}$ & 3367 & u & 9771 & c & 0.36 & $\mathrm{~cd}$ \\
\hline CV\% & 339 & & 6.582 & & 7.731 & & 10.160 & & 11.230 & & 5.283 & & 7.935 & & 10. & & 7.744 & \\
\hline LSD $\% 5$ & 6.753 & & 25.199 & & 1.391 & & 5.900 & & 0.225 & & 2.228 & & 32.162 & & 145.137 & & 0.032 & \\
\hline
\end{tabular}

* There is no statistical difference between the values shown with the same letters.

NPSM: Number of panicles per square meter, TGW: Thousand-grain weight, NGP: Number of grains per pnicle, PL: Panicle length, PH: Plant height, GWP: Grain weight per panicle, GY: Grain yield, TY: Total yield, HI: Harvest index 
The grain weights of the panicles were between 1.38$2.33 \mathrm{~g}$, while Haskara had the highest value, Dirilis, Fetih, and Kahraman cultivars were found in the lowest group (Table 4). According to the cultivars, there are significant differences between the grain weights in the panicle Dumlupinar et al. [17] have identified it in their research. Genotype affects the grain weight in a panicle significantly [15], and various variations occur with the effect of environment and genetic character $[8,18]$.

Thousand-grain weights of the cultivars were between 30.9-42.3 g, while Faikbey and Sari cultivars were in the highest group, and Dirilis remained at the lowest level (Table 4). Thousand-grain weights obtained in our study were at higher levels compared to the values obtained in similar studies, in this respect, the results were higher than Erbas and Mut [14] and Sari et al. [19]. This performance, which is seen in a thousand grain weights in the research, is an indication that the cultivars make better use of the from ecological conditions after-spiking. Because thousand-grain weight is a factor that affects grain yield [18], it is significantly affected by genotype and environmental factors.

The grain yields of the cultivars were between $2563-4134 \mathrm{~kg} / \mathrm{ha}$, the highest was found in Haskara and the lowest in Chekota (Table 4). As it reached similar results with our research, that the differences between grain yields according to cultivars are significant [6, $15,17]$. It is considered that the difference between the seasonal climate data is effective in the wide variation between grain yields. Because it has been stated that climate data affects grain yield with other factors [18].

Total yield values were formed between 7238-14584 $\mathrm{kg} / \mathrm{ha}$ and while Haskara and Kahraman cultivars were in the highest group, Fetih was found at the lowest level (Table 4). The results obtained in the study are similar to Erbas and Mut [16].

Harvest index data were realized between $31 \%$ and $41 \%$, and Fetih was in the highest group, Haskara,
Kahraman and Seydisehir cultivars were in the lowest group (Table 4). These results are similar to Gungor et al. [20], who found that the total yield affects the grain yield by $31.15 \%$.

According to the results of the two-year research, the highest PH was obtained from Faikbey, the highest NPSM obtained from Arslanbey, Kahraman, Kirklar and Seydisehir, the highest PL obtained from Haskara, Yeniceri and Faikbey, the highest NGP obtained from Haskara, the highest GWP obtained from Haskara, the highest TGW Faikbey and Sari, the highest GYobtained from Haskara, Seydisehir and Dirilis, the highest TY obtained from Faikbey, Kahraman and Seydisehir, the highest HI obtained from Fetih, Dirilis and Arslanbey cultivars. In this respect, it is understood that Faikbey, Haskara, Kahraman and Seydisehir cultivars show higher performance in terms of many traits other than HI, and Fetih variety has low performance compared to many other traits examined (Table 4).

\section{Correlation}

In the Table 5, the correlation coefficients between the examined characteristics of the oat cultivars used in the research are given.

Accordingly, a significant positive relationship between PH and PL $(r=0.651)$, the NGP $(r=0.586)$, TGW $(r=0.702)$, HI $(r=0.675)$, and TY $(r=0.750)$, on the other hand, it is seen that there is a very significant positive relationship. On the other hand, it is seen that there is a significant negative relationship between the NPSM and the GWP $(r=-0.500)$, while it is understood to be very significant positively between the PL and the NGP $(r=0.721)$. On the other hand, it was found that there is a very significant positive relationship between the NGP and the GWP $(r=0.695)$, and a significant negative relationship between the HI $(r=-0.411)$. Similarly, it was understood that there is

Table 5. Correlation coefficients for traits examined in oat cultivars according to Pearson

\begin{tabular}{|c|c|c|c|c|c|c|c|c|c|}
\hline & PH & NPSM & PL & NGP & GWP & TGW & GY & HI & TY \\
\hline PH & & -0.359 & $0.651^{*}$ & $0.586^{*}$ & 0.495 & $0.702 * *$ & 0.031 & $-0.675^{* *}$ & $0.750^{* *}$ \\
\hline NPSM & & & -0.294 & -0.539 & $-0.500^{*}$ & -0.082 & 0.249 & 0.225 & -0.140 \\
\hline PL & & & & $0.721^{* *}$ & 0.413 & 0.181 & 0.255 & -0.319 & 0.417 \\
\hline NGP & & & & & $0.695^{* *}$ & 0.030 & 0.372 & $-0.411^{*}$ & 0.464 \\
\hline GWP & & & & & & 0.224 & 0.258 & -0.139 & 0.247 \\
\hline TGW & & & & & & & -0.214 & -0.253 & 0.324 \\
\hline Y & & & & & & & & 0.017 & 0.214 \\
\hline HI & & & & & & & & & \\
\hline TY & & & & & & & & & $-0.927 * *$ \\
\hline
\end{tabular}

*. The correlation is significant at the 0.05 level, **. Correlation is significant at the 0.01 level

PH: Plant height, NPSM: Number of panicles per square meter, PL: Panicle length, NGP: Number of grains per panicle, GWP: Grain weight per panicle, TGW: Thousand grain weight, GY: Grain yield, HI: Harvest index, TY: Total yield 
Table 6. PATH coefficients for properties that directly and indirectly affect the grain yield in oat cultivars.

\begin{tabular}{|c|c|c|c|c|c|c|c|c|c|c|}
\hline & & \multicolumn{5}{|c|}{ Direct effects } & \multicolumn{4}{|c|}{ Indirect effects } \\
\hline \multicolumn{2}{|c|}{ Features } & GY & $\mathrm{PH}$ & NPSM & PL & NGP & GWP & TGW & $\mathrm{HI}$ & TY \\
\hline \multirow{2}{*}{$\mathrm{PH}$} & Coefficient & 1.288 & & 0.262 & -0.322 & 0.481 & -0.234 & -0.569 & 1.311 & -1.668 \\
\hline & $\%$ & 21.00 & & 4.27 & 5.25 & 7.84 & 3.81 & 9.27 & 21.37 & 27.19 \\
\hline \multirow{2}{*}{ NPSM } & Coefficient & 0.699 & -0.483 & & 0.151 & -0.471 & 0.248 & 0.068 & -0.301 & 0.340 \\
\hline & $\%$ & 25.32 & 17.49 & & 5.46 & 17.07 & 8.98 & 2.48 & 10.90 & 12.30 \\
\hline \multirow{2}{*}{ PL } & Coefficient & -0.467 & 0.887 & -0.225 & & 0.620 & -0.203 & -0.170 & 0.796 & -0.970 \\
\hline & $\%$ & 10.76 & 20.46 & 5.19 & & 14.29 & 4.69 & 3.91 & 18.44 & 22.35 \\
\hline \multirow{2}{*}{ NGP } & Coefficient & 0.811 & 0.763 & -0.406 & -0.357 & & -0.350 & -0.024 & 0.983 & -1.022 \\
\hline & $\%$ & 17.20 & 16.18 & 8.61 & 7.57 & & 7.43 & 0.50 & 20.84 & 21.67 \\
\hline \multirow{2}{*}{ GWP } & Coefficient & -0.477 & 0.630 & -0.363 & -0.199 & 0.595 & & -0.159 & 0.895 & -0.614 \\
\hline & $\%$ & 12.13 & 16.02 & 9.23 & 5.06 & 15.13 & & 4.04 & 22.76 & 15.63 \\
\hline \multirow{2}{*}{ TGW } & Coefficient & -0.768 & 0.953 & -0.062 & -0.103 & 0.025 & -0.099 & & 0.584 & -0.754 \\
\hline & $\%$ & 22.94 & 28.47 & 1.86 & 3.08 & 0.75 & 2.95 & & 17.44 & 22.52 \\
\hline \multirow{2}{*}{ HI } & Coefficient & -1.812 & -0.932 & 0.116 & 0.205 & -0.440 & 0.236 & 0.247 & & 2.115 \\
\hline & $\%$ & 29.69 & 15.27 & 1.90 & 3.36 & 7.21 & 3.86 & 4.06 & & 34.65 \\
\hline \multirow{2}{*}{ TY } & Coefficient & -2.190 & 0.981 & -0.108 & -0.207 & 0.378 & -0.134 & -0.264 & 1.750 & \\
\hline & $\%$ & 36.42 & 16.31 & 1.80 & 3.44 & 6.30 & 2.23 & 4.40 & 29.10 & \\
\hline
\end{tabular}

PH: Plant height, NPSM: Number of panicles per square meter, PL: Panicle length, NGP: Number of grains per panicle, GWP: Grain weight per panicle, TGW: Thousand grain weight, GY: Grain yield, HI: Harvest index, TY: Total yield

a very significant negative relationship between the HI and TY $(\mathrm{r}=-0.927)$ (Table 5).

While no significant correlation was found between $\mathrm{Y}$ and other parameters in our study, it was negatively significant between $\mathrm{Y}$ and $\mathrm{PH}$ in similar studies [20-21], between TGW [6] and HI [21] was found to be positively significant. Besides, it is stated that parameters such as NGP and GWP can be used in selection for yield [13]. Similar to the results of our study, it is positively significant between PH and TGW [6,20], between NGP and PL $[20,22]$ a correlation was determined. It has also been suggested that the dwarfism gene can be used to obtain new cultivars as an alternative to tall cultivars that tend to lodging [22].

\section{Path Analysis}

Path analysis, explained in the 1950s, is widely used in plant breeding studies and is still valid as an effective method in determining the criteria of selection in studies where plant characteristics are determined [23].

According to the combined results of the two-year research, the path coefficients of the properties that directly and indirectly affect the $\mathrm{Y}$ in oat cultivars and their effect rates are given in Table 6 .

Accordingly, the direct effect of $\mathrm{PH}$ on the GY is positive $(p=1.288)$, and the effect rate is $21.00 \%$.
While the highest indirect effect on the GY through the PH was negative and belonged to TY $(p=-1.668$, $27.19 \%$ ), the highest positive indirect effect was realized over the HI ( $\mathrm{p}=1.311,21.37 \%)$. The indirect effects of the features other than these on the Y through the PH are low, the NGP and the NPSM is positive, while the TGW, PL, and GWP is negative (Table 6).

The direct effect of the NPSM on the GY is positive $(p=0.699)$, the effect rate is at the level of $25.32 \%$. The highest indirect effect on the Y over the NPSM is from the $\mathrm{PH}(\mathrm{p}=-0.483,17.49 \%)$ and immediately after the NGP $(p=-0.471,17.07 \%)$ and its effects are negative. The highest positive indirect effect on the GY over the NPSM is from the TY ( $p=0.340,12.30 \%)$ and the indirect effects of the remaining PL, GWP, positive and negative HI are relatively lower (Table 6).

The direct effect of the PL on the GY is negative $(p=-0.467)$ and the effective rate is around $10.76 \%$. The highest indirect effect on the $\mathrm{Y}$ over the PL is in the negative direction and it is caused by the grain yield ( $p=-0.970,22.35 \%$ ), while the highest positive indirect effect is the PH ( $p=0.887,20.46 \%)$ and the HI and the NGP are indirectly and the effects were positive but relatively low. The indirect effects of the NPSM, GWP, and TGW on the GY over the PL are negative and low (Table 6).

The direct effect of the NGP on the grain yield is positive ( $p=0.811)$ and the effect is $17.20 \%$. The highest 
indirect effect on the GY over the NGP originates negative from the GY $(p=-1.022,21.67 \%)$ and this is followed by the positive HI ( $p=0.983,20.84 \%)$. While the indirect effect of PH $(p=0.763,16.18 \%)$ on the GY over the NGP is positive, the effects of NPSM, PL, GWP, and TGW are low and their effects are negative (Table 6).

The direct effect of GWP on the GY is negative $(p=-0.477)$ and its ratio is around $12.13 \%$. The highest indirect effect on GY over the GWP is positive and is caused by the harvest index $(\mathrm{p}=0.895,22.76 \%)$, the NGP and PH with positive indirect effects and the negative TY's effects are close to each other. In the remaining the indirect effects of the NPSM, PL, and TGWt on the NGP are negative and are realized lower (Table 6).

The direct effect of TGW on GY is negative $(p=-0.768)$ and its ratio is at the level of $22.94 \%$. The highest indirect effect on GY over a TGW is positive and is caused from the PH $(\mathrm{p}=0.953,28.47 \%)$, followed by the negative effect of TY ( $p=-0.754,22.52 \%)$ and the HI, which has a positive indirect effect right after it. Apart from these, while the NPSM, PL, and GWP have negative and low indirect effects on the grain yield over the TGW, the effect of the NGP is positive and low (Table 6).

The direct effect of the HI on the GY is negative $(\mathrm{p}=-1.812)$ and its ratio is around $29.69 \%$. The highest indirect effect on the GY through the $\mathrm{HI}$ is positive and it causes from the TY $(\mathrm{p}=2.115,34.65 \%)$, is followed by the negative effect of the PH ( $p=-0.932,15.27 \%)$. The indirect effects of all the remaining features except the NGP are positive and their ratios are low (Table 6).

The direct effect of the TY on the GY is negative $(p=-2.190)$ and its ratio is $36.42 \%$. The highest indirect effect on the GY over the TY is positive and it is caused from the HI ( $p=1.750,29.10 \%)$ and this is followed by the PH ( $p=0.981,16.31 \%)$, whose effect is also positive. The indirect effects of the other features, except the NGP, on the GY through the total yield, are negative and low (Table 6).

In the study, the highest positive direct effect on GY was provided by the NPSM $(\mathrm{P}=0.699,25.32 \%)$ and it was followed by $\mathrm{PH}(\mathrm{P}=1.288,21.00 \%)$, besides, the highest negative direct effect was from TY $(\mathrm{P}=-2.190$, $36.42 \%)$, and it followed by HI ( $\mathrm{P}=-1.812,29.69 \%)$, and TGW $(\mathrm{P}=-0.768,22.94 \%)$. It was also determined that the highest positive indirect effect on GY occurred through TY (P = 2.115, 34.65\%) over HI, followed by HI $(\mathrm{P}=1.750,29.10 \%)$ over TY and PH $(\mathrm{p}=0.953$, $28.47 \%$ ) over TGW. In this respect, it has been revealed that these features can be used as selection criteria in breeding studies.

In some studies similar to our study, positive direct effects on GY were provided by TGW (0.35) and, NGP $(0.22)$ and negative direct effects by GWP $(-0.40)$ and PH (-0.24) [25], NGP and grains larger than $2 \mathrm{~mm}$ have a positive direct effect on the industrial yield of oats., and the parameters that have an indirect effect on GY should be studied to improve the genetics of industrial yield in grains [28]. According to Gungor et al. [24] GY stated that the highest direct positive effect was provided by NGP $(29.80 \%)$ and the negative effect was provided by GWP (-24.78\%), and positive and negative effects should be evaluated together to obtain early cultivars.

While Oral and Ulker [25] found that TGW had the highest positive direct effect on GY, Boru et al. [10] stated that this effect is caused by GWP and TGW has the highest negative effect and also the negative

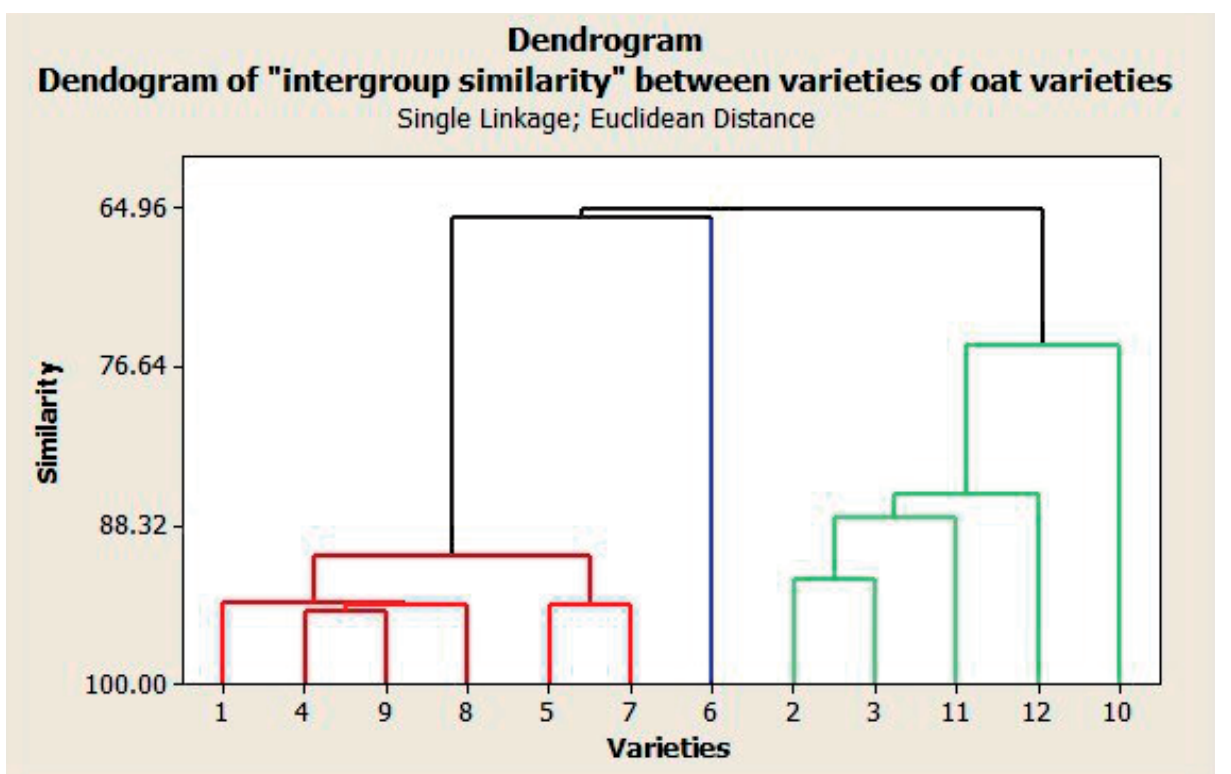

Fig. 1. Intergroup similarity (clustering) dendogram of the traits examined in oat cultivars.

1: Albatros, 2: Arslanbey, 3: Chekota, 4: Dirilis, 5: Faikbey, 6: Fetih, 7: Haskara, 8: Kahraman, 9: Kirklar, 10: Sari, 11: Seydisehir. 12: Yeniceri 
Table 7. Cluster analysis data of traits examined in oat cultivars.

\begin{tabular}{|c|c|c|c|c|}
\hline Rank & $\begin{array}{c}\text { Cluster } \\
\text { number }\end{array}$ & $\begin{array}{c}\text { Similarity ratio } \\
\%\end{array}$ & \multicolumn{2}{|c|}{ Cultivar } \\
\hline 1 & 11 & 94.5915 & 4 & 9 \\
\hline 2 & 10 & 94.2288 & 4 & 8 \\
\hline 3 & 9 & 94.1304 & 5 & 7 \\
\hline 4 & 8 & 94.0692 & 1 & 4 \\
\hline 5 & 7 & 92.3705 & 2 & 3 \\
\hline 6 & 6 & 90.6155 & 1 & 5 \\
\hline 7 & 5 & 87.7502 & 2 & 11 \\
\hline 8 & 4 & 86.0553 & 2 & 12 \\
\hline 9 & 3 & 75.0717 & 2 & 10 \\
\hline 10 & 2 & 65.6114 & 1 & 6 \\
\hline 11 & 1 & 64.9566 & 1 & 2 \\
\hline
\end{tabular}

direct effect of TGW is determined by Tonk et al. [9]. Dogan and Senyigit [26] reported that the NGP and TGW, Ramazani et al. [27] PL and TGW can be used as selection criteria. Gelalcha and Hanchinal [28] found that $\mathrm{PH}$ had the highest direct effect on GY, and Polat et al. [29] found that it is made by the NGP and GWP.

\section{Clustering Analysis of the Examined Features}

In the cluster analysis, which aims to bring similar materials together in the same cluster or groups, the classification is made according to the proximity (similarity) or distance (difference) criteria of the two observations.

The cluster dendogram of the similarity of 9 traits examined in 12 oat cultivars in the study is given in Fig. 1.

It is understood that the cultivars of oats differ by $64.96 \%$ and $35.04 \%$. In the dendogram, it is seen that 3 main groups are formed and there are 2, 3, 11, 12, and 10 cultivars in the $1^{\text {st }}$ main group, while the 2 nd main group has the number 6 and the 3rd main group is divided into two subgroups. These, 3 (1). cultivars 1, 4, 9 , and 8 and 3 (2) in the subgroup. In the subgroup, there are cultivars numbered 5 and 7 (Fig. 1). The distribution types of the cultivars used in the study in the main and subsets are explained as the genotypes with the same genetic structure are located in close groups [5].

The data regarding the clustering analysis of the traits examined in oat cultivars are given in Table 7. Accordingly, the similarity rates of the cultivars in the dendogram, which consists of 12 clusters, vary between $94.59 \%$ and $64.96 \%$. In terms of the characteristics examined, it is seen that the closest cultivars to each other are the cultivars numbered 4 (Dirilis) and 9 (Kirklar), the most distant cultivars are the cultivars numbered 1 (Albatros) and 2 (Arslanbey).
Cluster analysis is carried out to determine the effect and distribution of quality and agronomic traits in genotypes on genetic variability $[10,30,31,32]$.

In similar studies conducted for this purpose; Farooq et al. [38] determined that among the genotypes collected in 15 groups, the closest group 15 and number 1 , and the farthest group number 9 and 8 . Boru et al. [10] determined that according to the cluster analysis of agronomic characteristics, genotypes were divided into 1 main and 2 sub-clusters, and the similarity rates varied between $39.28 \%$ and $97.91 \%$, and the most similar lines were 12 and 13 lines, and lines 1 and 11 were the most similar. has done. Sari and Unay [33] explained that according to the dendogram results, oat genotypes were collected in 4 main groups showing $22.05 \%$ difference and $77.95 \%$ similarity. According to the cluster analysis results of the performances of 15 wheat cultivars, two groups were formed under normal conditions and three groups under drought stress, and they explained that tolerant cultivars can be used as parents in breeding and breeding programs [34].

\section{Conclusions}

According to the results of the two-year research, the highest grain yield; was obtained by Haskara, Seydisehir and Dirilis, the highest total yield; by Faikbey, Kahraman and Seydisehir, the highest harvest index; by Fetih, Dirilis and Arslanbey. According to the correlation results of the agronomic traits, while there was no significant relationship between $\mathrm{Y}$ and other traits, there were significant positive correlations between plant height and panicle length, number of grains per panicle, thousand grain weight, harvest index, and total yield. Significant negative relationships were determined between the number of panicles per square meter and the number of grain per panicle and the grain weight per panicle. A significant positive correlation was observed between the panicle length and the number of the grain per panicle. Positive and significant relationships between the number of grain per panicle with grain weight per panicle, negative and significant relationships between with the harvest index has emerged. It was determined that there is a negative and significant relationship between the harvest index and total yield.

According to the results of the path analysis, it was determined that the highest positive direct effect on yield was provided by the number of panicle per square meter $(\mathrm{P}=0.699,25.32 \%)$, while the highest negative direct effect came from the total yield $(\mathrm{P}=-2.190$, $36.42 \%)$. Also, it was determined that the highest positive indirect effect on yield was realized through the total yield $(\mathrm{P}=2.115,34.65 \%)$ via the harvest index. In this respect, considering the direct and indirect effect rates, it has been revealed that the number of panicle per square meter and the total yield, plant height and harvest index can also be used as selection 
criteria in breeding studies. According to the cluster analysis results of the characteristics examined, it was understood that the cultivars of oat were $64.96 \%$ similar and $35.04 \%$ different. In the dendogram, it is seen that 3 main groups are formed.

\section{Conflict of Interest}

The author declare no conflict of interest.

\section{References}

1. TOPAL A., SADE B., SOYLU S., AKAR T., MUT Z., AYRANCI R., SAYIM I., OZKAN I., YILMAKART M. National cereals council barley - rye- oats- triticale report. 2015.

2. FAO. Data of the Worldwide oats production. Available online: http://faostat.fao.org/site/567/default.aspx\#ancor. (accessed on 28.02.2021). Evaluation in terms of features. Ordu Univ. Know. Single. Journal. 1 (1), 22, 2011.

3. ERYIGIT T., TUNCTURK M., TUNCTURK R. Determination of the nutritional and chemical composition of some edible wild plants used in herby cheese. J. Elem., 25 (3), 1127, 2020.

4. ANONYMOUS. Turkey Statistical Institute, Available online: http://www.tuik.gov.tr/pretablo.do?alt_id=100. (accessed on 28.02.2021)

5. SARI N., UNAY A. Beta Glucan Content of Some Oat Genotypes Evaluation of Cluster Analysis. Journal of Field Crops Central Research Institute, 22 (1), 6, 2013.

6. MUT Z., ERBAS KOSE O., AKAY H. Kernel yield and some quality characteristics of groats oat varieties. Anatolian Journal of Agricultural Sciences, 31 (1), 96, 2016.

7. ALTUNER F., ULKER M. The effect of different sowing densities and nitrogenous fertilizer doses on yield and yield components in oat (Avena sativa L.). Academic Studies on natural Health Sciences Edition:1, Chapter: 23, 299, 2019.

8. DUMLUPINAR Z., DOKUYUCU T., MARAL H., KARA R., AKKAYA A. Evaluation of turkish oat landraces based on morphological and phenological traits. ZemdirbysteAgriculture, 99 (2), 149, 2012.

9. TONK F.A., ISTIPLILER D., TOSUN M. Traits relationships and path analysis in some common wheat (Triticum aestivum L.) genotypes. Ege Univ. Faculty of Agriculture. Journal., 54 (1), 85, 2017.

10. BORU K., YILDIRIM S., AYDOGAN CIFTCI E. Investigation of yield and yield components in common wheat genotypes by correlation and path analysis. Turkish Journal of Agriculture and Natural Sciences 6 (3), 379, 2019.

11. ANONYMOUS. Research area vegetation periods and AoLY climate data. Available online: https://www. mgm.gov.tr/veridegerlendirme/il-ve-ilceler-istatistik. aspx?m=VAN Records of the General Directorate of Meteorology. (accessed on 28.02.2021).

12. SARI N. Relationships between yield and yield components in oats (Avena sativa L.). Adnan Menderes University, Know Science. Inst., Field Bit. USA, 96, 2012.

13. NASER A.F., AL-MOTHEFER AA. Effect of seeding quantity and chemical fertilizer on growth and grain yield of oats (Avena sativa L.). Jornal of Al-Muthanna for Agricultural Sciences, 6 (1), 77, 2018.

14. ERBAS O.D., MUT Z. Determination of agricultural and some quality traits of pure line oat genotypes. $10^{\text {th }} \mathrm{Crops}$ Plant Cogress of Turkey. September 10-13, 2013. Konya, Turkey.

15. KILINC F.M. Turkey to determine the origin of some agronomic traits in oat genotypes and associated local mapping analysis. Kahramanmaras University, Institute of Science, PhD thesis 226p. 2020.

16. KADIOGLU Y. An Assessment of the Effects of Extreme Weather Events on Agricultural Activities in the Case of Carsamba Plain. TUCAUM International Geography Symposium, 528-537, 13, October 2016, Ankara, Turkey.

17. DUMLUPINAR Z., THOMPSON A.S., HEREK A., TANRIKULU A. DOKUYUCU T., AKKAYA A. Turkey origin oat genotypes evaluation to certain agricultural properties. Turkish Journal of Agriculture, Food Science and Technology, 5 (7), 763, 2017.

18. SABANDUZEN B., AKCURA M. Investigation of yield and yield components of some oat genotypes in Canakkale conditions. Turkish Journal of Agricultural and Natural Sciences 4 (2), 101, 2017.

19. SARI N., IMAMOGLU A., PELIT S., YILDIZ O., BUYUKKILECI C. Determination of oat (Avena sativa L.) genotypes suitable for the Aegean Region coastal belt. Journal of Field Crops Central Research Institute, $\mathbf{2 5}$ (Special Issue-1), 156, 2016.

20. GUNGOR H., DOKUYUCU T., DUMLUPINAR Z., AKKAYA A. Determination of the relationship between yield and some agricultural traits in oats (Avena spp.) By correlation and path analysis. Journal of Tekirdag Agricultural Faculty, 14 (1), 61, 2017.

21. DUMLUPINAR Z.K. Correlation and path analysis of grain yield and yield components of some Turkish oat genotypes. Pure. J. Bot, 44 (1), 321, 2012.

22. KRISHNA A., AHMED S., PANDEY H.C., KUMAR V. Correlation, path and diversity analysis of oat (Avena sativa L.) Genotypes for grain and fodder yield. Journal of Plant Science \& Research 1 (2), 1, 2014.

23. AYDOGAN CIFCI E., DOGAN R. Relationship between traits and path analysis in some triticale ( $x$ triticosecale Witmack.) genotypes grown in Bursa ecological conditions. Uludag University Faculty of Agriculture Journal, 32 (1), 59, 2018.

24. HAWERROTH M.C., GONZALEZ DA SILVA J.A., WOYANN L.G., ZIMMER C.M., GROLI E.C., COSTA DE LIVEIRA A., DE CARVALHO F.I.F. Correlations among industrial traits in oat cultivars grown in different locations of Brazil. Australian Journal of Crop Science (AjCS) 9 (12), 1182, 2015.

25. ORAL E., ULKER M. Relationships between traits and path analysis in triticale ( $x$ triticosecale Wittmack) types. Igdir Uni. Science Inst. Der., 6 (3), 153, 2016.

26. DOGAN R., SENYIGIT E. Correlation and path coefficient analysis of yield and yield components in hexaploid triticale ( $x$ Triticosecale Wittmack) genotypes under Mediterranean conditions. J. Biol. Environ. Sci., 10 (28), 21, 2016.

27. RAMAZANI S.H.R., TAJJALI H., GHADERI M.G. Correlation and path coefficient analysis for determining interrelationships among grain yield and related characters in Iranian genotypes of triticale. Bulgarian Journal of Crop Science, 54 (1), 35, 2017.

28. GELALCHA S., HANCHINAL R.R. Correlation and path analysis in yield and yield components in spring 
bread wheat (Triticum aestivum L.) genotypes under irrigated condition in Southern India. African Journal of Agricultural Research, 8 (24), 3186, 2013.

29. POLAT K.P.O., CIFCI E.A., YAGDI K. Determination of the relationship between grain yield and some yield elements in bread wheat (Triticum aestivum L.). Journal of Agricultural Sciences, 21, 355, 2015.

30. KAHRAMAN F., EGESEL, C. Agronomic and quality analysis of different types of bread bu_day

31. SAVII G., NEDELEA G. Analysis of phenotypic diversity in winter wheat for some yield traits. Journal of Horticulture, Forestry and Biotechnology. 16 (1), 119, 2012.
32. BHATTARAI R.P., THAPA D.B., OJHA B.R., KHAREL R. SAPKOTA M. Clusteranalysis of elite spring wheat (Triticum aestivum L.) genotypes based on yield and yield attributing traits under irrigated condition. International Journal of Experimental Research and Review (IJERR). 10, 9, 2017.

33. FAROOQ M.O., KASHIF M., KHALIQ I., RASHID $\mathrm{K}$. Correlation and cluster analysis to estimate genetic variability in triticale. J. Agric. Res., 54 (3), 343, 2016.

34. NAGHAVI M.R., KHALILI M. Evaluation of genetic diversity and traits relations in wheat cultivars under drought stress using advanced statistical methods. Acta agriculturae Slovenica, 109-2, September 2017 str. 403-415, 2017. 